time spora becomes re-established, they disappear mysteriously. Petri dishes $(9 \mathrm{~cm}$. diam.) of medium exposed horizontally for ten minutes at the beginning of each period during a similar series of tests on July 24-25 gave 1, 7, 5, 4, 5 and 28 colonies respectively of Sporobolomyces. Their occurrence as a significant element of the air spora does not appear to have been recorded hitherto; but Mr. Merfyn Richards (in lit.) informs me that this observation confirms earlier experiments in which he trapped large numbers of Sporobolomyces on plates exposed during the night at Llandough Hospital in August 1951.

Another group of minute hyaline spores in the second and third fractions consisted of rod-shaped, jointed or septate spores. The smallest of these could possibly be confused with bacilli ; but bacteria would not be expected to occur singly, free in the air, in large numbers, though some Actinomycetes might do so. Some of this fraction may consist of ascospores, but its composition is at present obscure and merits further investigation because of its potential interest in plant pathology. Some structurally characterless minute hyaline spherical spores have probably been overlooked and omitted from the count.

The fourth fraction is free from plant spores, but contains a copious deposit of smoke particles. The absence of spores among the smallest particle fraction on the fourth slide shows that all particles in the sizerange of plant spores are deposited on the first three stages, and that the cascade impactor can be relied upon to give a reasonably undistorted picture of the entire air spora. The emptiness of the fourth slide gives confidence in the end point.

The cascade impactor thus allows a preliminary visual examination of the whole air spora, and shows that the smaller spores make up a very large proportion of the total number present. 'This was not shown by the surface traps in general use, which although giving some information of the relative abundance of large spore types at different times, are heavily weighted in favour of larger spores. For a comparison of the relative concentration of different spore types at any time the data given by surface traps can perhaps not unfairly be described as a logarithmic lie.

The species making up the smaller size fraction of the dry air spora are largely unknown, but transient clouds of small hyaline basidiospores occur during the night in high concentration. Well-marked fluctuations with time of day and changes in weather, differing with different species, are also observed, and have been studied in greater detail in both dry and damp air by Hirst ${ }^{5,6}$, using the more convenient automatic volumetric spore trap. Simultaneous comparisons in the field between the cascade impactor and the Hirst trap have shown that the models of the latter at present in use retain spores of all sizes with a higher efficiency than previously expected.

The greater part of the solid material larger than $1 \mu$ suspended in the atmosphere in dry weather under our conditions consists, not of inorganic dust, but of plant spores of one sort or another. It is clear that increasing knowledge of the air spora depends on the wider use of power-operated sampling equipment such as the cascade impactor for spot sampling, or the Hirst automatic volumetric trap for continuous records. The results obtained at Rothamsted show for the first time that a quantitatively complete picture of the air spora can be obtained. The possibility is opened up of applying these methods at other times and in other places and of attempting to correlate the findings with the occurrence of crop diseases and of respiratory allergy.

${ }^{1}$ Committee on Apparatus in Aerobiology, Phytopathology, 31, 201 (1941).

${ }^{2}$ Gregory, P. II., Nature, 168. 487 (1950); Ann. App. Biol., 38, 375 (1951), and unpublished.

${ }^{3}$ Bourdillon, R. B., I.diwell, O. M., and Thomas, J. C., J. Hyg., Camh., 41, 197 (1941).

'May, K. R., J. Sci. Instr., 22, 187 (1945).

${ }^{5}$ Hirst, J. M., Ann. Amp. Biol., 39. 257 (1952), and unpublished.

G Gregory, P. H., and Hirst, I. M., Nature, 170, 414 (1952).

\section{THE NORTH OF ENGLAND INSTITUTE OF MINING AND MECHANICAL ENGINEERS}

\author{
By Prof. GRANVILLE POOLE \\ King's College, Newcastle upon Tyne
}

$\mathrm{A}$ $\mathrm{N}$ event of great historical interest to the mining industry in Great Britain occurs this year, for the members of the North of England Institute of Mining and Mechanical Engineers are celebrating the hundredth anniversary of its formation in 1852 .

Most fortunately, the first president-Nicholas Wood-was a man of outstanding ability and foresight. $\mathrm{He}$ was born in 1795 and in early life was thrown into the society of George Stephenson, to whom he became an assistant in that series of persevering experiments which at last resulted in the steam locomotive. Mr. Wood made the drawings from which, under its inventor's instructions, the Stephenson safety lamp was constructed. Mr. Wood also accompanied Stephenson to Darlingtion to engineer the Stockton and Darlington Railway. He wrote a book on the "Establishment and Economy of Railways" in 1825 .

On July 3, 1852, a meeting of coal owners and 'viewers' in-Newcastle resulted in the formation of a Society called "The North of England Society for the Prevention of Accidents" ; but at a second meeting the title was changed to "The North of England Institute of Mining Engineers". As mining involved much engineering, it was considered desirable to include engineers among its members, and the title was later again changed to its present form.

Mr. Wood's contributions to the Transactions of the Institute included articles on the relative value of steam jets and furnaces to increase the ventilation of mines; on safety lamps; on the conveyance of coal underground; on sinking shafts through the water-bearing magnesian limestone and on the geology of the Northern Coalfield in Great Britain. $\mathrm{He}$ also paved the way for the establishment of a collegiate institution "for the cultivation, improvement and the teaching of mining science".

Nicholas Wood's inaugural address displayed that high sense of professional obligation and resolve which activated the original members and which resulted in the growth of the stature of the Institute being recognized in 1876 by the grant of a royal charter by Queen Victoria. The following tribute is to be found in this charter: "that it has during its existence of a period of nearly a quarter of a century steadily devoted itself to the preservation of human life and the safer development of mineral property, that it, has contributed substantially and beneficially to the prosperity of the country and the welfare and happiness of the community". 
By this time the Institute membership had grown to more than eight hundred, and in terms of the charter "included a large proportion of the leading Mining Engineers in the United Kingdom". Indeed, a review of the list of members reveals that membership was beginning to be world-wide, and the Institute was becoming a clearing-house of technical information on coal mining in many countries.

The example set by the North of England was followed by the formation of mining institutes in other coalfields, and the North of England Institute played a leading part in the establishment in London in 1889 of the Institution of Mining Engineers-now a federation of eight mining institutes from all parts of Britain.

Many historic papers have been read at the meetings of the North of England Institute. In the early years, when many disastrous explosions occurred, particular attention was paid to the ventilation of mines. John Buddle, the "father of English mining', realizing the possible danger of using a furnace to assist in the natural ventilation, invented an air pump-the forerunner of the modern fan. A series of papers by J. J. Atkinson on the principles of mine ventilation laid the foundation of modern ventilation technology. Though Humphry Davy had improved the then safety lamp, his 'Davy lamp' was proved to be unsafe in certain circumstances and improvements were gradually brought about.

Many valuable papers on methods of working and the control of the strata are to be found in the Transactions of the Institute. With regard to methods of working coal seams, as the very shallow seams became exhausted it became necessary to sink deeper shafts and to work a greater area from each shaft, and the first method of really underground working was evolved, namely, the room and pillar method of mining. G. C. Greenwell in 1852 wrote "A Practical Treatise on Mining Engineering" at a time when there was practically no literature on mining in the English language. The first edition was based on a series of lectures delivered at the Newcastle College of Practical Science-the forerunner of the King's College of to-day. In passing, reference may be made to a statement made by a prominent mining engineer in the United States of America to the effect that their modern method of working is based more or less on Greenwell's ideas.

'The Institute had from time to time set up committees to study specific mining problems, and in 1924 "The Support of Workings in Mines Committee" was appointed to investigate the causes of falls and accidents due to falls. In 1930 the Committee was provided with funds by the Safety in Mines Research Board for the appointment of a full-time investigator. 'The reports of this Committee provide a comprehensive statement of the fundamental factors determining the behaviour of the strata in mining operations.

In 1948 the Northern Divisional Strata Control Research Committee of the National Coal Board was set up. The Committee has a membership representative of the Durham and Northern Divisions of the Coal Board and of the North of England Institute of Mining and Mechanical Engineers, including members of the staff of the Mining Department of King's College, University of Durham. In this way the Institute has been enabled to continue its contributions to its historic work in this field. This is an ideal combination of observation and experiment in mines, together with academic work in the Univer- sity such as photo-elastic research on plastic models of mine workings.

The early pioneers would have been astounded if they could have listened to the most recent paper read at a meeting of the Institute, when successful experiments were described in the getting of coal from very thin seams without any men on the working face at all. Such is the progress made in the mechanization of mining operations.

With such grand traditions, it will not be surprising that the North of England Institute of Mining and Mechanical Engineers is still very actively engaged in research to secure the increased safety and health and well-being of those employed in the mining industry. In addition to the research mentioned on roof control and prevention of falls of ground, there are committees on the lighting and ventilation of mines.

The research on lighting is being carried out with the view, ultimately, of being able to predict the performance of any lighting fitting under any set of mining conditions. The series of tests being done at the moment are designed to investigate the effect of shape of a mine roadway and the reflexion factor of its walls and roof on the utilization factors. This work is being done in the Mining Laboratories at, King's College, Newcastle upon Tyne, and tests are also being carried out underground so as to obtain a continual correlation of results. A special photometer has been designed and constructed with which the spherical distribution of any source can be found. Investigations also cover the safety of fluorescent lamp units for use in gassy mines, and a safe signalling system on longwall faces.

The immediate object of the research on ventilation is the formulation of rules and formulæ as the basis for the design of fan drifts.

The first meetings of the Institute were in the lecture room of the Literary and Philosophical Society at Newcastle upon Tyne; but through the enthusiastic efforts of its members and with the co-operation of the coal owners, the present well-known home of the Institute, Neville Hall, Newcastle upon T.yne, was built and opened in 1872 .

The beautiful Wood Memorial Hall Library and ideally arranged lecture theatre, together with the other offices provided, bear witness to the professional spirit aroused by the inauguration of the Institute, and have done much to inspire succeeding generations of mining and mechanical engineers in devotion to the task of following the objectives so clearly set out by Nicholas Wood.

In order adequately to maintain this building and to ensure continuity in research, a Centenary Appeal Fund has been opened, and it is hoped that the appeal will meet with generous response.

\section{INTERNATIONAL SEAWEED SYMPOSIUM}

$\mathrm{A}$ $\mathrm{N}$ international seaweed symposium, organized by the Institute of Seaweed Research, the University of Edinburgh and the Scottish Marine Biological Association, with the assistance of corresponding delegates from Australia, Canada, Chile, France, Germany, New Zealand, Norway, South Africa, Spain, Sweden and the United States of America, was held in Edinburgh during July 13-17. The symposium, which was the first of its kind, 